\title{
SHORT NOTE \\ The long term need for the Libyan commercial ports planning. Misurata, Al-Khums and Tripoli ports as case study
}

\section{Fathi M. ESAHIRI ${ }^{1}$}

\author{
1. University of Tripoli, Tripoli, Libya. \\ mesehiri@hotmail.com
}

\begin{abstract}
:
The planning of a new port, expansion or improvement of an existing one, requires many factors to be taken into consideration. For commercial ports, as well as oceanography considerations, the main factors are the nature of cargoes to be handled, size and type of ships to be served, and the land area for storage and smooth integration with land transport system. The volume of foreign and local trade of the country, the rate of growing of population and spatial development are the main points to be noted in any planning process.

For a country as Libya and due to its strategic location in Africa and Mediterranean, transport planning should consider local requirements and serving the landlocked countries, namely Chad and Niger. The discovery of oil and other resources recently in both countries is an encouraging element. Nearly third of global trade and forty per cent of Africa trade with EU countries pass through the Mediterranean (UNCTAD, 2009).

Development of transport corridors from Libya's coast, to Chad, Niger and Sudan, initially by road and potentially by rail could provide better economic results than using the present routes through Nigeria or Cameron. The share of transportation cost in the export and import trade in these countries is about fifty per cent.
\end{abstract}


The paper highlights the impacts of having modern ports on the Libyan coast as hub and transit ports which will be well integrated with efficient land transport network on the economic performance and the spatial development of the country. It is possible to develop two or three north-south corridors which can serve adjacent landlocked countries. The cost of infrastructures needed is expected to be high, but the development can be done step by step and to be performed in parallel with economic and security improvements in the region.

Libya is one of the member countries covered by The European Neighbourhood Policy (ENP), which aims at bringing Europe and neighbours closer, to mutual benefit and interests. It is worthwhile, to get assistance from TAIEX, which is the technical information exchange instrument of the European Commission. A master plan for transport system aiming the integration of all modes of transport that links Libya with Europe and Africa can be made.

\section{Introduction}

Libya has nine commercial ports along its coast, namely Zawara, Tripoli, Al-Khums, Misurata, Ras Lanouf, Brega, Benghazi, Derna and Tobruk. The approximate capacity of these ports is fourteen million metric tons of bulk, and general cargo and containers per year, on single shift basis. Description of these ports is available on port authority websites.

All ports are owned and managed by public sector, except Misurata Port, which is owned and managed by Free Zone Company (MFZ, website). All ports are not yet on the standard level of competition with other hub ports in the area. A lot of planning works is needed to be done to achieve that. One of the objectives is to draw the attention to the fact that the rapid changes in shipping and transportation technology necessitate a good planning to maintain maximum flexibility in order to be able to adapt to changed conditions. Classification or rehabilitation of Libyan ports to function as main and coastal ports is advisable. Long term strategic plan and short term master plan are essential in the planning process of all Libyan ports and land transport network in general for successful country development.

\section{The role of Libyan Ports, in country trade and economic development}

The estimation of Libyan population statistics in 2010 was approximate six millions with an average growth rate of two percent (BSC LIBYA, 2010). The annual normal volume of trade is about ten million metric tons per year excluding oil and its products. Libya is one of the important countries in oil and gas export, and supposed to perform huge development all over the country as soon as local conditions will be appropriate. A study for long-term transport strategy is worthwhile to be initiated as basic requirement for the spatial and sustainable development. The transport issue is a very delicate subject, because Libya area is 1.8 million square kilometres, $90 \%$ of which is desert. 
The strategic location of Libya to sub-Saharan and Mediterranean countries, qualify the country in the future to activate transit trade business and its income on long-term can be one alternative resources to oil income.

The production of oil in Chad and Niger and other mineral resources and the uncertainty access to South African coast could add value to the long-term transport strategy in Libya. Oil pipe lines of Elephant oil fields in the south of Libya are close to Niger and Chad boarders. From engineering and economic points of view, the land network and topography of the south west of Libya, qualify some Libyan ports to serve the southeast of Algeria more efficiently than Algerian ports (Figure 1).

It is important to mention that a lot of studies had been made by different consultants for different public enterprises for each port, but not within an overall strategy of the whole country, i.e. a lack of consistency and integration between such ports. The role of land transport network, and storage areas related to port efficiency was not considered seriously. A revision should be made for such studies to be upgraded and long term strategic study could be done. This paper presents a case study for the following three ports, assuming all Libyan ports to be included in any future national strategy transport study.

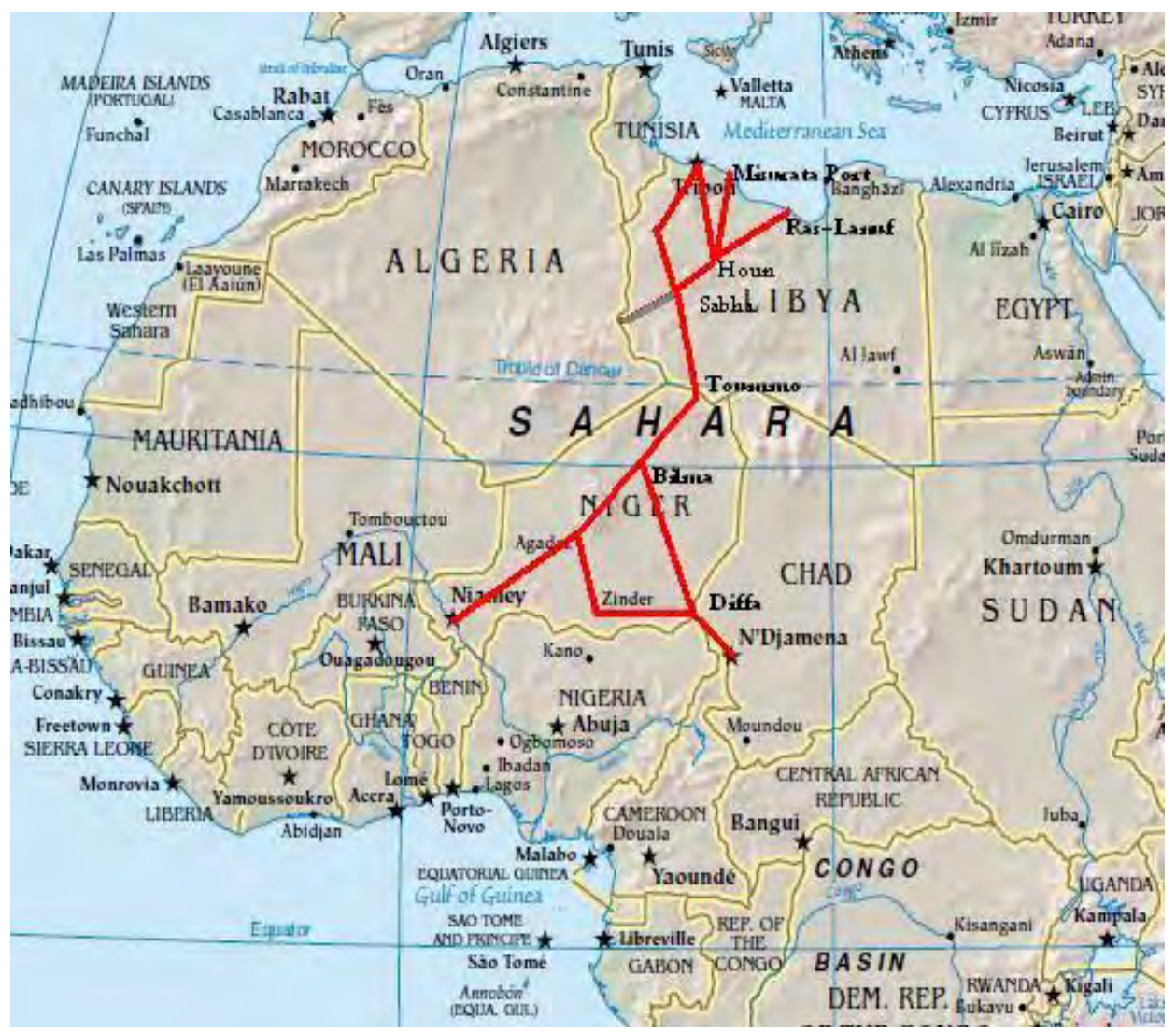

Figure 1. Schematic transport corridor North-South. 


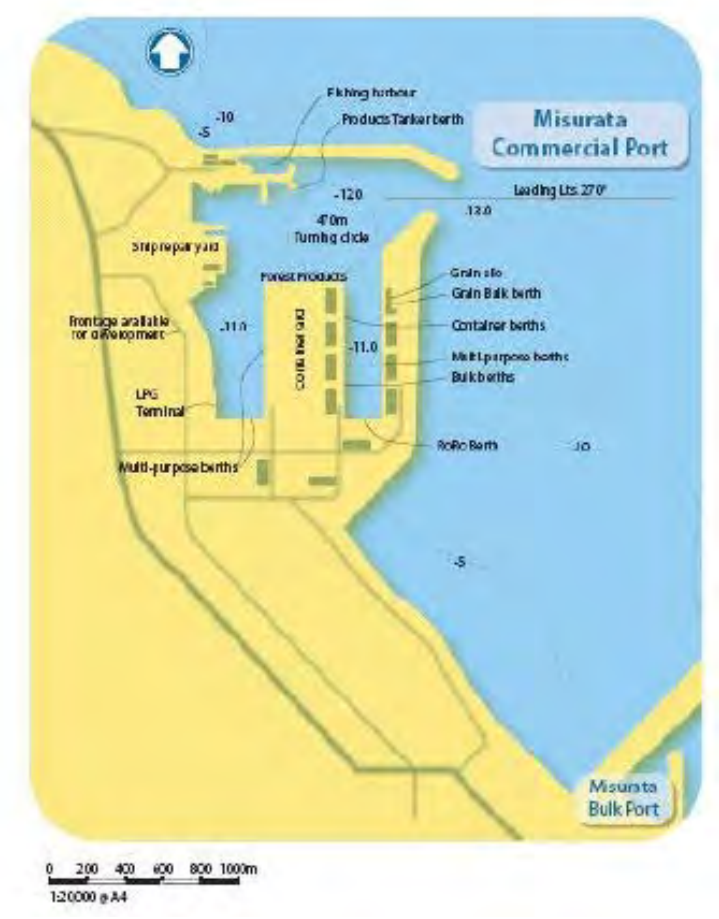

Figure 2. Existing Misurata port layout.

\subsection{Misurata Free Zone port}

This port is a specific and efficient port, it has an excellent hinterland and good access to land transport network, with substantial storage area (Figure 2):

- total area of 190 hectares,

- total quay length of 4150 metres,

- depths range between 6-13 metres,

- open storage yards of 60 hectares,

- covered storage warehouses of 67500 square metres,

- grain silos with 40000 ton capacity,

- modern stevedoring equipment and machinery, with well-trained technical staff: 5 tugboats; 2 pilot boats; 1 marine survey boat; 4 gantry cranes (2 RTG \& 2 STS); 11 harbour mobile cranes of 60-100 tons capacity; 12 reach stackers of 45 tons capacity (5 containers height); 12 top left cranes of 45 tons capacity; 7 forklift of 12.5 tons capacity; 4 side cranes of 12.5 tons capacity; 10 forklifts of 3,5 and 7 tons capacity.

The present capacity of the port is six million tons per year, and ten million per year is targeted for future development. Statistics show its market share is about $50 \%$ of the throughput in Libya. In 2006, 2,031,000 tons of cargo was handled as a maximum figure in the last ten years. A lot of scenarios for its development are under consideration by MFZ (ESAHIRI, 2012), but such development has been postponed due to a lot of reasons, mainly lack of availability of funds and investors. 


\subsection{Tripoli port}

This port has been functioning efficiently for a long time, handling all types of cargo, although it had limited land areas, but storage areas outside the port were available and not far away. In recent years, and due to city expansion (figure 3), constrains were made on its access to land transport network and its storage areas. The southern part of the port (about $2000 \mathrm{~m}$ of quay berths) became idle for municipality interests. The port's efficiency was therefore, greatly reduced. In the last ten years, 1,497,000 tons was the maximum cargo handled in 2006. Historically, what happened to London and Amsterdam ports has also occurred for this port.

The rapid maritime technology development in recent years and population growth with increased requirement of development were elements, not properly considered when this port was redeveloped in the seventies of last century, in other words flexibility of port expansion was not considered.

The harbour basin area is approximately five and half million square metres, while only seven hundred thousand square metres of land storage area are available inside the port. The total length of the quay berths, in its north part is two thousands metres with a maximum depth of twelve metres. The lack of land area inside the port, made installation of gantry cranes for container terminal a difficult task.

Al-Khums and Misurata ports can be the alternatives, since they have appropriate infrastructures, and are located in the same zone of activities and population accumulation.

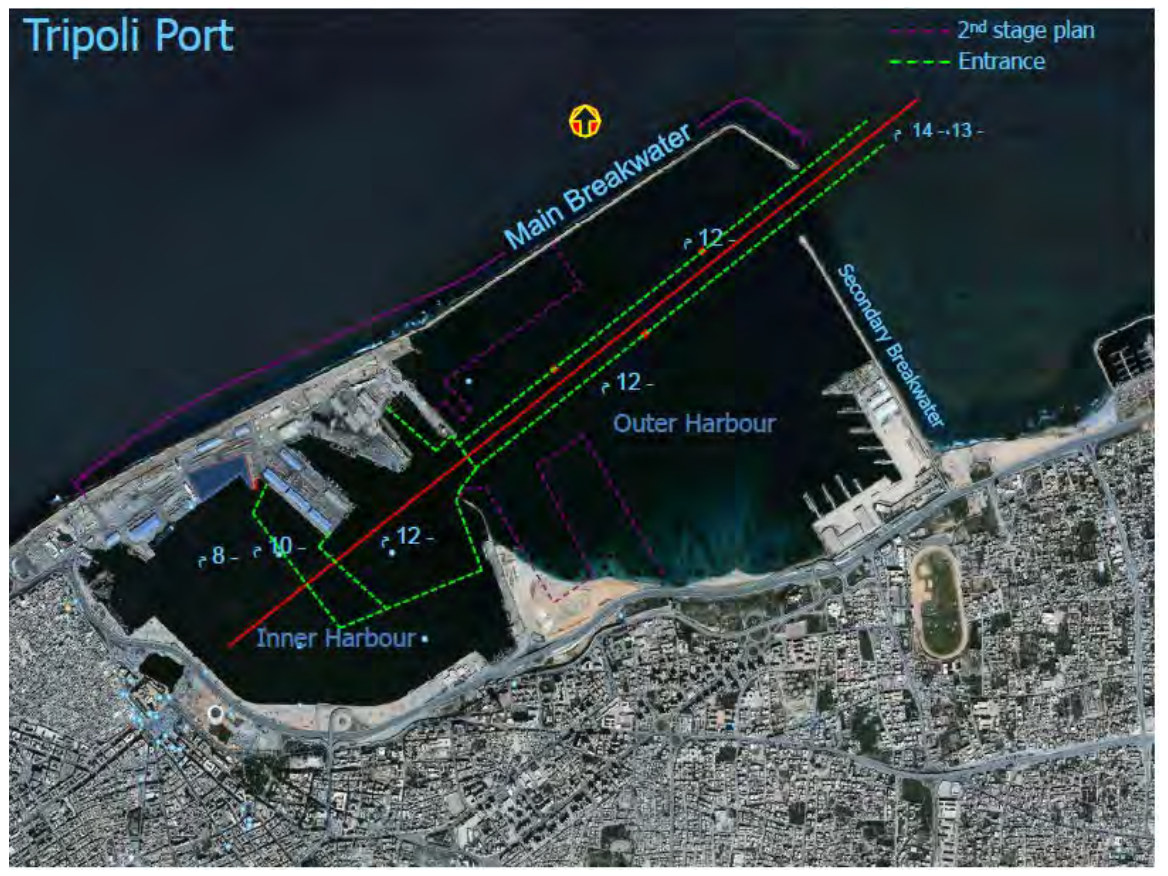

Figure 3. General satellite view of Tripoli port and city centre. 


\subsection{Al-Khums port}

This port is situated $110 \mathrm{~km}$ east of Tripoli, operated by The Libyan Port Company (LPC), under the patronage of The Libyan Maritime Port Authority (LMPTA). It has berthing quays of approximate six thousands metres length and their depths range from seven to thirteen metres. The total harbour basin area is two million square metres, and having one million square metres of reclaimed storage area, protected by two breakwaters of five kilometres length (GENTILOMO, 1986). The targeted capacity of the port is five million metric tons per year, while at present time it handles much less than this figure. The highest figure handled by this port was 446,000 tons, in 2012. General cargo, cars and containers are major types of cargo being handled. No silos yet available. Completion of development stages is needed to be more efficient. The expansion inside the harbour basin to receive larger vessels is possible (figure 4).

The local Authority and National Planning decision makers should preserve the master plan in order to keep the flexibility of its future expansion and its free access to land transport network, and storage areas, to avoid the constraints that happened to Tripoli port.

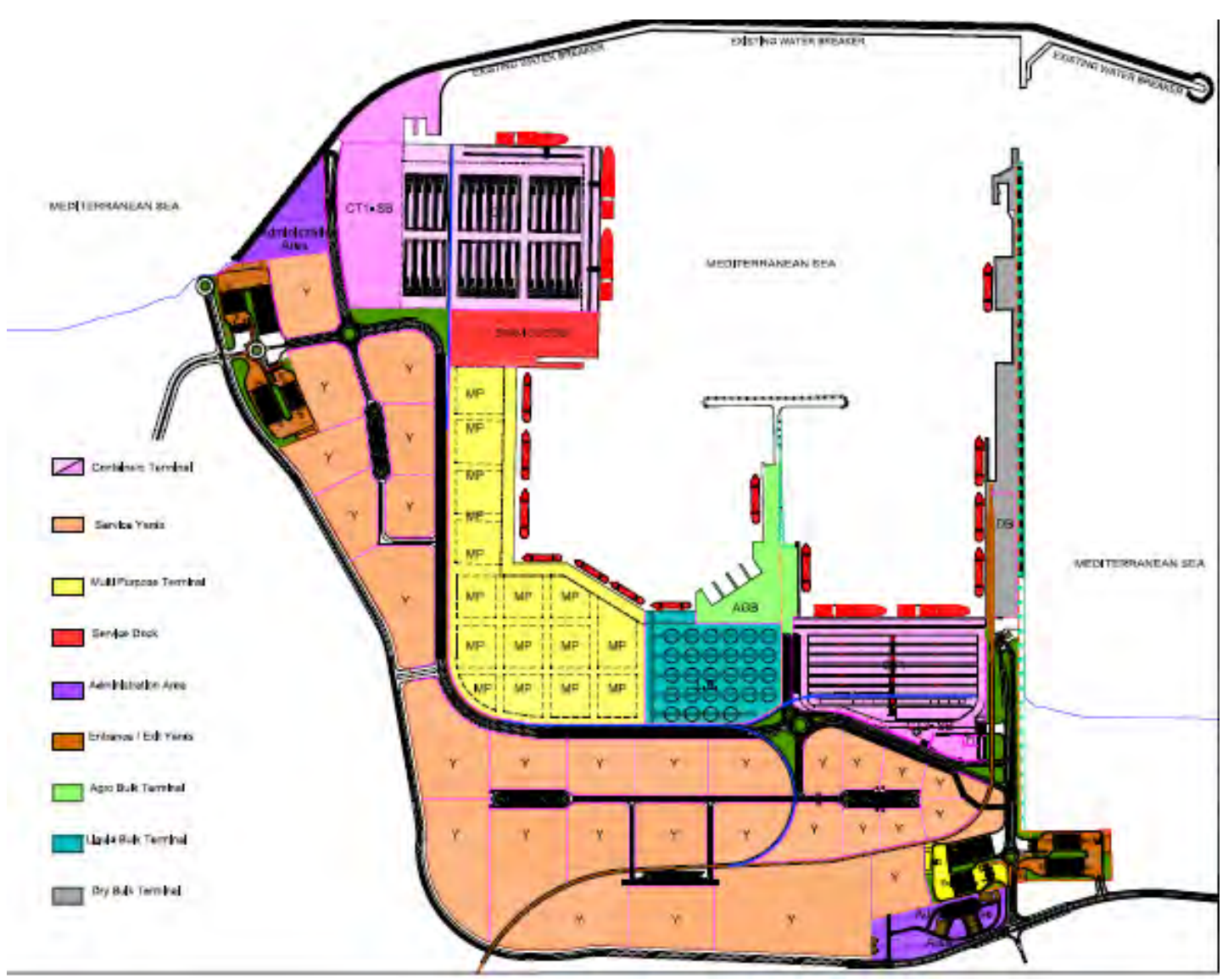

Figure 4. Al-Khums port general layout. 


\section{Results}

Considering recent field visit to Al-Khums port, and study made for the other two ports, it appears in this period of hard economic situation and shortage of financial resources that, Al-Khums port can be rehabilited and upgraded by local contractors with lower cost, to be ready when normal trade activities resume in Libya as part of short term measures, in other words, the delay of Misurata port development, and inadequacy of Tripoli port for expansion, qualify this port to be as interim port in the area.

It is worthwhile, to mention that Libya in early seventies of last century faced a great problem of lack of adequate port facilities for the requirements of development projects when it started. Some urgent solutions were made and even some Tunisian ports were employed to overcome that problem. All those measures resulted in high costs of development projects.

The development and expansion of MFZ, can be implemented on long term basis when financial resources will be available. Priority now should be given, to its land transport network development and upgrading. That can be done by local contractors with lower costs. In other words, the study of long term planning could start, meanwhile projects on short term basis could be initiated, giving priority to land transport network and limited works to qualify existing maritime facilities, due to its high cost.

\section{Conclusions}

The role of Libyan ports development in the overall country sustainable and spatial development plan is great. Port development is necessary to achieve successful economic results. All the existing commercial ports need development and upgrading within an over-all strategy plan. Having high class land transport system linking all ports, cities and places of economic activates is of vital importance to increase ports capacities and performance. Some of the existing ports could be targeted as hub and transit ones. Al-Khums and Misurata are considered in this paper but other ports could be investigated, such as Zuara, Azzawia, Benghazi and Tobruk.

Tripoli port development plans should concentrate on maintenance and not expansion, to keep it functioning for specific light trade and passengers.

The long term ports plan can include setting of interim three-year or five-year stages, and make-use of works done by the "Libya 2030 Vision Committee" formed by Ministry of Planning, taking into consideration international security and environmental standards. Foreign investments, public and private participation, integration and competition between ports elements are not be ignored too.

Employment issue, management, operation, mechanization, and relation with local authorities are vital factors to be considered. The development of free zones and transit trade with land locked countries must be linked to the availability of adequate land transport network in addition to security matters. 
It is strongly recommended to ask national and international professionals and experts to perform strategic plan for transport in Libya. TAIEX can be one of the teams that perform this task, assuming Libya as one of ENP members. To the knowledge of the author, most of data, statistics and requirement's identification can be easily traced.

\section{References}

ESAHIRI F.M. (2012). Misurata Free zone port development can serve south of Libya and neighbor landlocked countries. XII ${ }^{\mathrm{ème}}$ Journées Nationales Génie Côtier - Génie Civil, Cherbourg, pp 725-732. http://dx.doi.org/10.5150/jngcgc.2012.078-E

GENTILOMO M. (1986). The construction of the New Port of Homs in Libya, Precast concrete elements in marine works. PIANC Bulletin No. 55, pp 57-73.

MFZ -Misurata Free Zone- (website). http://www.mfzly.com

BSC LIBYA -Bureau of Statistics and Census of Libya- (2010). Statistics Book 2010.

UNCTAD -United Nations Conference on Trade and Development- (2009). Review of Maritime Transport. United Nations Publication, 184 p. 